IRA-International Journal of Education \& Multidisciplinary Studies

ISSN 2455-2526; Vol.08, Issue 01 (July 2017)

Pg. no. 75-79

Institute of Research Advances

http://research-advances.org/index.php/IJEMS

\title{
A Study of Academic Achievement in Relation to Mental Health among Pahari Students in Secondary Schools of Poonch District
}

\author{
Dr. Afa Dul Mujiaba \\ Lecturer Department of Education \\ Govt. Degree College Nowshera (J\&K), India.
}

Type of Review: Peer Reviewed.

DOI: http://dx.doi.org/10.21013/jems.v8.n1.p8

How to cite this paper:

Mujiaba, A. (2017). A Study of Academic Achievement in Relation to Mental Health among Pahari Students in Secondary Schools of Poonch District. IRA International Journal of Education and Multidisciplinary Studies (ISSN 2455-2526), 8(1), 75-79. doi: http://dx.doi.org/10.21013/jems.v8.n1.p8

(C) Institute of Research Advances.

\section{(cc) BY-NC}

This work is licensed under a Creative Commons Attribution-Non Commercial 4.0 International License subject to proper citation to the publication source of the work.

Disclaimer: The scholarly papers as reviewed and published by the Institute of Research Advances (IRA) are the views and opinions of their respective authors and are not the views or opinions of the IRA. The IRA disclaims of any harm or loss caused due to the published content to any party.

Institute of Research Advances is an institutional publisher member of Publishers Inter Linking Association Inc. (PILA-CrossRef), USA. The institute is an institutional signatory to the Budapest Open Access Initiative, Hungary advocating the open access of scientific and scholarly knowledge. The Institute is a registered content provider under Open Access Initiative Protocol for Metadata Harvesting (OAI-PMH).

The journal is indexed \& included in WorldCat Discovery Service (USA), CrossRef Metadata Search (USA), WorldCat (USA), OCLC (USA), Open J-Gate (India), EZB (Germany) Scilit (Switzerland), Airiti (China), Bielefeld Academic Search Engine (BASE) of Bielefeld University, Germany, PKP Index of Simon Fraser University, Canada. 


\begin{abstract}
The major trust of this study was to examine the academic achievement of pahari students in relation to their mental health. The present study was carried-out on sample of 200 pahari students selected from 6 secondary schools of Poonch district of Jammu and Kashmir through stratified random sampling technique. Mental health scale developed by Dr. Mercy Abraham and Dr. K.C. Baby Prasanna was used to collect required information, while the total marks obtained by the students in the previous class were used as an achievement criterion. Two statistical techniques like Pearson's product moment method and 't' test were used to analyze the data. The study shows that there is a positive correlation between academic achievement and mental health of students. The result of the study further revealed significant differences between boys and girls as well as rural and urban students in regard to their mental health. On the basis of these findings some suggestions both for practice and further studies have been put forward by the author.
\end{abstract}

Key-words: Academic Achievement, Mental Health, Secondary schools and Pahari students.

\title{
Introduction:
}

Mental health of the student is very crucial for effective learning and all round development of personality. The child is born in a home where role of mother is great, traditionally it is said that a mother is equal to hundred teachers, undoubtedly role of family cannot be undermined or shifted to any other agency. But due to changes in the social processes and social structure, the family is not in a position to contribute much for the developmental aspect of the child as a result school has become an important agency and assumes great responsibility in developing the personality of a child. Mental health is one of the most important factors which is associated with academic achievement of the student. Higher the mental health of the students better is their educational performance (Mehdi Bostani, Amir Nadri, Azami Rezaee Nasab 2014). Several researchers like Taviyad Manshingbhai S. 2013, Verma K. 2013, Jasbir Kaur and Babita Arora, 2014) found positive correlation between academic achievement and mental health of secondary school students. Prasanna (1984) conducted a study on relationship between academic achievement and mental health of students and concluded that there is a positive relationship between academic achievement and mental health of the student. Sufficient number of researchers has paid their attention towards finding-out the relationship between academic achievement and mental health of the students, but it is very difficult to find-out even a single study in which academic achievement and mental health of Pahari students have been studied. Thus, present study is a humble attempt to bridge this research gap by comparing the academic achievement and mental health of pahari students in secondary schools of district Poonch of Jammu and Kashmir.

\section{Objectives of the study:}

1. To find-out the relationship between academic achievement and mental health of Pahari students in secondary schools of Poonch district.

2. To compare the mental health among pahari male and female students.

3. To compare the mental health among rural and urban pahari students.

\section{Hypothesis of the study:}

1. There is no significant relationship between academic achievement and mental health of Pahari students.

2. There is no significant difference between pahari male and female students in regard to their mental health.

3. There is no significant difference between rural and urban students in regard to their mental health.

\section{Methodology and Design of the study:}

After preparing the list of all the secondary schools of district Poonch a stratified sample of 6 secondary schools was selected to ensure due representation of rural and urban as well as male and female students. In the second phase, the researcher randomly selected 200 pahari students from both rural and urban areas as the sample of the study.

\section{(i) Tool used:}

In order to measure the mental health of the students a standardized mental health scale by Dr. Mercy Abraham and Dr. K.C. Baby Prasanna was used. 


\section{(ii) Statistical Techniques used:}

Pearson's coefficient of correlation was used for knowing the relationship between academic achievement and mental health of secondary school students. Furthermore, In order to find-out the significance of difference between the means of different comparative groups ' $t$ ' test was used. The data was analyzed with the help of computer by using statistical package for social sciences (SPSS) version 16 to get accurate results and also to save time.

\section{Analysis and Interpretation of Results}

Table no.1.1 showing the correlation between academic achievement and mental health

\begin{tabular}{|c|c|c|c|c|c|}
\hline Category & $\begin{array}{c}\text { No. of } \\
\text { students }\end{array}$ & $\mathrm{df}=\mathrm{N}-2$ & 'r' Value & P value & Remarks \\
\hline Academic Achievement & 200 & 198 & 0.540 & $\begin{array}{c}\text { Significant at } \\
0.01 \text { level of } \\
\text { confidence }\end{array}$ \\
\hline Mental Health & 200 & 198 & & \\
\end{tabular}

Table no. 1.1 depicts that the calculated ' $r$ ' value is greater than the table value at 0.01 level of confidence. Hence the null hypothesis i.e "There is no significant relationship between academic achievement and mental health of Pahari students is rejected. The rejection of null hypothesis clearly indicates that there is a significant co-relation between academic achievement and mental health of pahari students in secondary schools of Poonch district. This finding is in harmony with the results of Taviyad Manshingbhai S. 2013, Verma K. 2013, Jasbir Kaur and Babita Arora, 2014 who found significant or positive correlation between mental health and academic achievement of secondary school students.

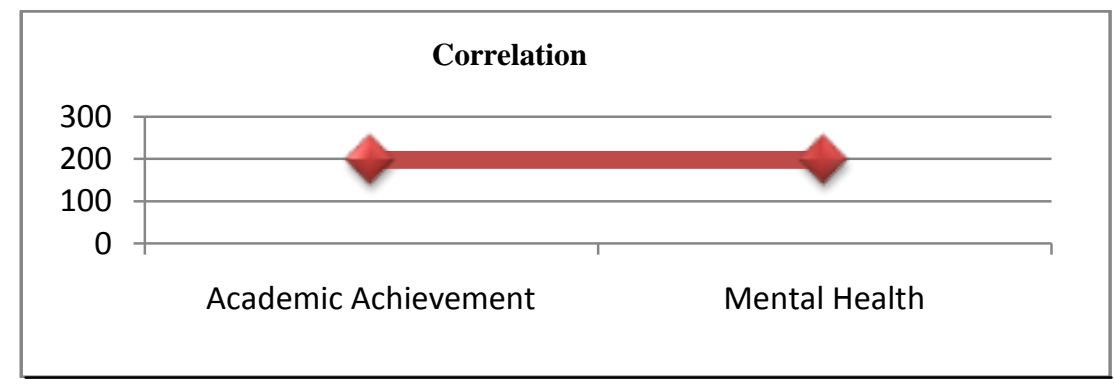

Table no 1.2. Showing the comparison between male and female students in regard to their mental health

\begin{tabular}{|c|c|c|c|c|c|}
\hline Variable & $\begin{array}{c}\text { No. of } \\
\text { students }\end{array}$ & Mean & SD $t$ ' Value & Remarks \\
\hline Pahari Males & 100 & 86.2 & 14.1 & 2.44 & $\begin{array}{c}\text { Significant at } \\
0.05 \text { level of } \\
\text { confidence }\end{array}$ \\
\hline Pahari Females & 100 & 81.83 & 9.96 & \\
\end{tabular}

Above table 1.2 shows the comparison of mean scores of male and female students on the measure of mental health. The obtained ' $t$ ' value is found to be significant at 0.05 level of confidence showing the difference between two compared group. The mean value (86.2) of pahari males is greater than the mean value (81.83) of pahari female. 
Thus it can be said that mental health of pahari males is better than pahari females. So the null hypothesis i.e "There is no significant difference between pahari male and female students in regard to their mental health is rejected.

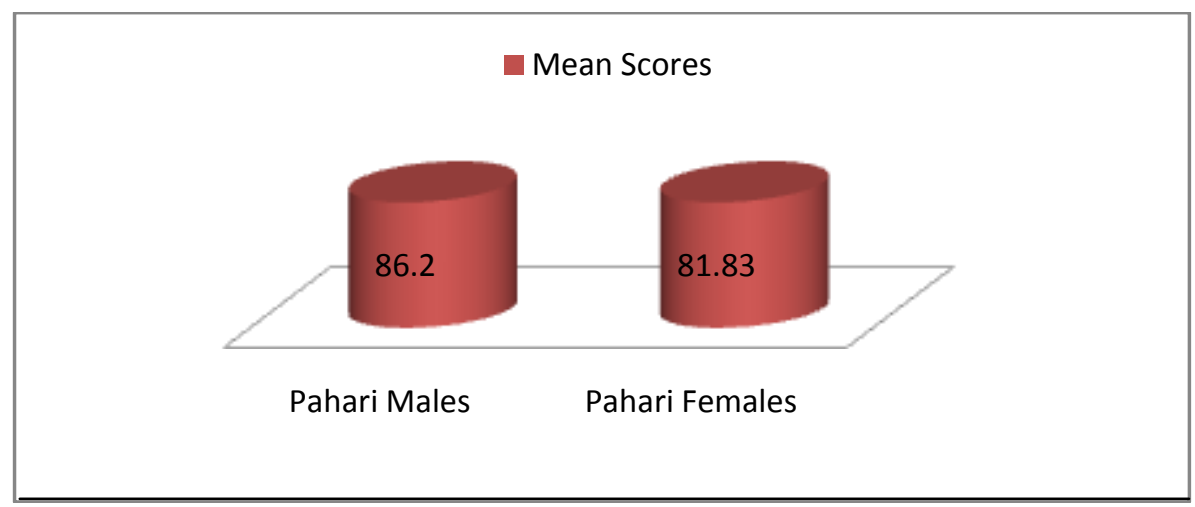

Table no 1.2 Showing the comparison between rural and urban students in regard to their mental health

\begin{tabular}{|c|c|c|c|c|c|}
\hline Variable & $\begin{array}{c}\text { No. of } \\
\text { students }\end{array}$ & Mean & SD & 't' Value & Remarks \\
\hline Rural & 100 & 79.7 & 11.1 & & 5.09 \\
\hline Urban & 100 & 88.1 & 12.1 & $\begin{array}{c}\text { Significant at } \\
0.01 \text { level of } \\
\text { confidence }\end{array}$ \\
\hline
\end{tabular}

Above table 1.3 explains the comparison of mean scores of rural and urban pahari students on the measure of mental health. The calculated 't' value (5.09) is found to be significant at 0.01 level of confidence. It can be said that there exist a significant difference between rural and urban pahari students. The mean value of urban students is found to be 88.1 which is greater than the mean value of rural students being 79.7. Thus it can be concluded that urban students have better mental health than their rural counterpart. The null hypothesis i.e "There is no significant difference between rural and urban students in regard to their mental health is rejected.

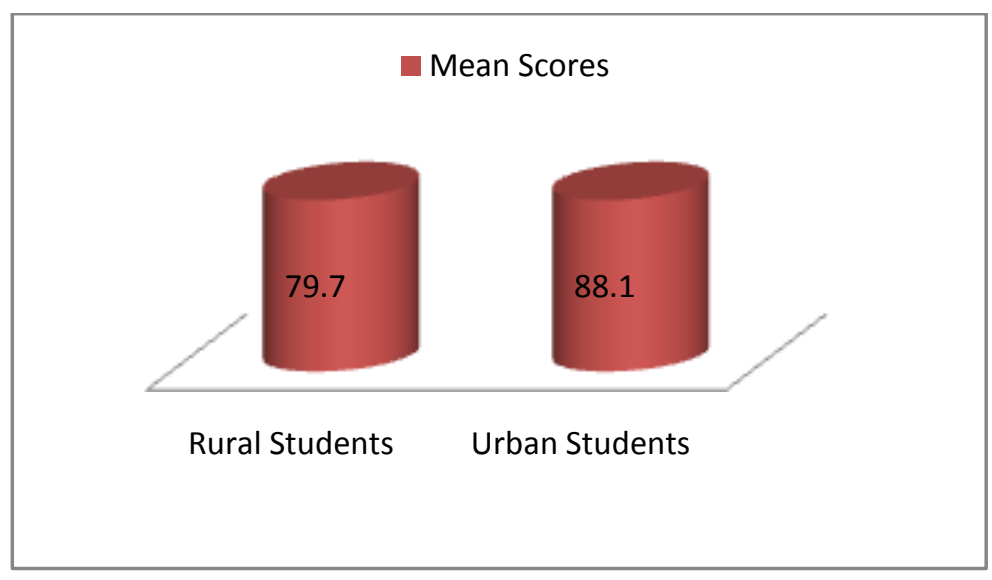

\section{Conclusion and Suggestions:}

Mental health is considered as one of the most important variable which influences child's academic achievement. The present study revealed positive co-relation between academic achievement and mental health of pahari students. Furthermore, study found significant differences between boys and girls as well as rural and urban samples in regard to their mental health. In order to eradicate mental illness among students following suggestions have been given. 


\section{Educational Implications:}

- Teacher should take keen interest in creating a healthy, attractive and friendly environment in the classroom where child can freely ask their doubts without any hesitation.

- Guidance and counseling cells as well as mental health services should be introduced in each and every school of the state for protecting the child from mental illness or behavioural problems.

- Co-curricular activities should be an integral part of the curriculum to discharge the pent-up feelings of students and to use their unhealthy energy in a healthy way.

- Corporal punishment should be abolished. Strict community vigilance against the corporal punishment in the schools should be imposed. Seminars and conferences should be organized to discuss the ways and means to ensure self discipline.

- Social and emotional learning programme should also be an integral part of curriculum.

\section{Research Implications:}

- Comparative studies among Pahari and Non-Pahari students in respect to their socio-economic status may be taken up.

- Researches may be carried-out on broader perspectives in more districts of Jammu and Kashmir and other states of India.

- $\quad$ Projects may be taken up on academic achievement of tribal and non-tribal students.

\section{References:}

1. Balilashak, N. Safavi, M. \& Mahmoudi, M. (2010). Comparative Assessment of Mental Health of Gifted and Average students of Junior High School.Procedia - social and behavioural sciences, 5, 2010, 2027 2033.

2. Katherine L. Dix, Phillip T. Slee, Michael J. Lawson \& John P. Keeves (2012). Implementation Quality of whole-school Mental Health promotion and students' Academic Performance, Child and Adolescent Mental Health Volume 17, No. 1, 2012, pp. 45-51

3. Philip H. Winne and John C. Nesbit (2009). The Psychology of Academic Achievement, Vol. 61: 653-678, DOI: 10.1146/annurev.psych.093008.100348

4. Sujatha, K. (1987). Education of the Forgotten Children of the Forests A Case Study of Yennadi Tribe, Konark Publishers, New Delhi.

5. Verma, K.(2013). Mental Health and Academic achievement among secondary students. Indian Journal of Psychometry and Education, 44(1): 64-67. 